TAPROBANICA, ISSN 1800-427X. October, 2009. Vol. 01, No. 02: pp. 111-114.

(C) Taprobanica Nature Conservation Society, 146, Kendalanda, Homagama, Sri Lanka.

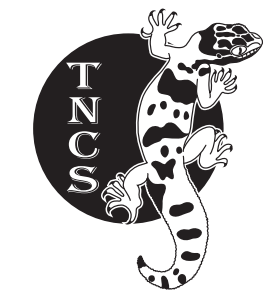

\title{
AN ABERRANT SPECIMEN OF Calotes grandisquamis GÜNTHER, 1875 (REPTILIA: AGAMIDAE) WITH COMMENTS ON ITS ALTITUDINAL DISTRIBUTION
}

\author{
S. R. Chandramouli
}

Department of Zoology, Division of Wildlife Biology, A.V.C. College, Mannampandal, Mayiladuthurai, Tamil Nadu, India: Email: findthesnakeman@gmail.com

\begin{abstract}
An adult female Calotes grandisquamis with unusual colouration was recorded from a low elevation plantation site near the foothills of the Ponmudi Hills, Western Ghats, which proves to be the lowest altitude from which this species has ever been recorded.
\end{abstract}

Keywords: Abnormal coloration, Ponmudi Hills, Western Ghats

\section{Introduction}

Abnormal coloration in Indian reptiles has been reported earlier in several taxa (Kuch, 1991; Wall, 1908; Whitaker, 1968). Calotes grandisquamis Günther, 1875 is an agamid lizard endemic to Western Ghats (Das, 2002; Murthy, 1985; Smith, 1935), which was originally described by Günther from the foot of the Canoot Ghat (= near Mananntoddy, Bramagherry Hills, fide Smith, $1935)$ i.e., now Mananthavady ( $11^{\circ} 48^{\prime} \mathrm{N}, 76^{\circ} 00^{\prime}$ E; $740 \mathrm{~m}$ asl.) in the Brahmagiri Hills of Wynaad District, Kerala State, and is known to be distributed in the Brahmagiri, Anamalais, Ponmudi and Tirunelveli hills (Ishwar et al., 2003; Murthy, $1985 ; 1990 ;$ Smith, 1935). This report of an aberrant individual is based on a live adult female recorded from the foothills of the Ponmudi hill range, Thiruvananthapuram district, Kerala State, India.

\section{Observation}

A live adult female was sighted on $26^{\text {th }}$ March 2009 at $09.11 \mathrm{hrs}$ on a rubber tree at a height of about $1.85 \mathrm{~m}$ from the ground in a private plantation bordering a road in Vithura town, Thiruvananthapuram District ( $8^{\circ} 40^{\prime} 13^{\prime \prime} \mathrm{N}, 77^{\circ} 05^{\prime}$ 32" E; $107 \mathrm{~m}$ asl.), a locality amidst human habitations. Dorsum bright green, with three distinct, white transverse bars on body, each 